\title{
Translation and Vernacular Literary Modernity: A Study of French Works in Tamil
}

\author{
Jagadeesan $\mathrm{T}$ \\ Centre of Indian Languages, School of Language, Literature \& Culture Studies, \\ Jawaharlal Nehru University, New Delhi, India
}

\begin{abstract}
The main focus of this paper is to analyze the French works available in Tamil translation and the various literary and cultural changes that have taken place in the Tamil context. As far as the literary scene is concerned, in the period 1950-70, Tamil received and was consequently influenced by various western literatures like English and French. French fictions written by Victor Hugo, Guy de Maupassant, Alexandre Dumas, Emile Zola, Jules Verne and other famous authors were widely translated. In the 1980s, famous works of Albert Camus and Jean Paul Sartre were translated directly from French. Translations of the above said authors' works led the Tamil writers to experiment with form, content and narrative style and thus gave newness to their creative process. Translations from western languages were often linked with the discourse of literary modernity in Tamil. Thus, this paper tries to trace the routes of literary modernity in Tamil in the purview of translations from French.
\end{abstract}

Keywords: Translation, Vernacular, Literary Modernity, Influence.

\section{Introduction}

In the age of globalization, analyzing the issue of literary modernity of vernacular languages in general and languages such as Tamil in particular finds a place in the current debates in interdisciplinary research. Modernity, as a debate in literary studies includes translation as an important area to explore how literary modernity has evolved with translations from one language to another over the time. Thus translation finds a place not only in the history of literature but also literary history, an area which is not explored much in historiography.

In this context, the relation between Tamil and French is undoubtedly hierarchical. The colonial relationship between these two cultures is visible in the material that has been translated in the last two centuries and is itself a worthy field to explore. During the time, unlike French, Tamil received a considerable number of works from French continuously. The reception of French works in Tamil even around 30 years ago was mainly in the fields of literature, culture and religion and was rarely scientific knowledge. Reception in the last 30 years is undoubtedly in the field of 'Literature' and 'Philosophy', a generalized space that includes all 'systems' of knowledge. One who keenly observes the contemporary Tamil literary production may not disagree with the claim that the strong influence of French literature and thought either directly or indirectly influences the production of Tamil contemporary literary sensibility.

In the case of translations from French into Tamil, it is interesting to note that most of the early translations were adaptations. These adaptations were well received and played a significant role in shaping the political and literary trends in Tamil. For example, the continuous translations and adaptations from French in 1940s and 50s helped in framing the ideologies of the Tamil political movement in that particular period. Intellectuals and leaders of Dravidian and Communist movements took the initiative of translating progressive thoughts into Tamil. These French translations were extensively used as supporting materials by Tamil writers to expand political and social awareness among the people.

Translation involves commission, needs audience in a culture for whom it is translated, patrons and publishers whose role is involved in the selection of texts for translating as well as the ways in which these texts are to be translated, among many other factors. It would be interesting to analyze these factors because 
translations of French texts into Tamil, though growing in number, seem to be bound by many of these factors. Fiction - novels and short stories - are the most translated, interspersed with poems and drama. Translators and publishing houses involved in publications are limited in number. Conflicts between superior and inferior cultures, so evident during the period of colonization in India and efforts at preserving the self-identity of one particular culture are giving way to more progressive efforts as is reflected in contemporary Tamil literature.

\section{Translation of Western Literature into Tamil}

Tamil has long history of translation activities throughout its literary evolution. With the advent of print, the first European encounter happened here with the translation of Bible in Tamil in 1774. English, the language of colonial rulers has the most number of literary works translated to Tamil from 1870 to recent times. This started with the translation of Shakespeare's Merchant of Venice as C. Kanaga Nayakam (1981: 19-29) observes that this was the first step taken to accommodate Shakespeare with the Tamil literary world. Apart from English, French, German and Russian literature were also widely translated into Tamil in the first part of the $20^{\text {th }}$ century. It was in this connection, Tamil literature started exposing itself to the new form and content. In the first phase, the translators of the western literature into Tamil were mostly writers as they tried many varieties of translation practices such as adaptation, imitation, summary translation and re-writing the original according to the receivers end and so on.

These trends were prominent in translating/writing popular fiction in Tamil in the 1920s to 40s. The likes of Reynolds and other European crime/detective fictional works were translated and circulated in large numbers as the readership grew steadily among Tamil middle class. Popular fiction writers like Vaduvur Duraisamy Iyengar, J.R. Rangaraju and others took the plot of the original and made it anew after adding character names according to Tamil readers to show that it is Tamil fiction rather than a 'translated' one. It was the same period of time when Shakespeare's plays were largely translated into Tamil and writers like Pammal Sambanda Mudaliyar translated them in large scale and took inspiration from Shakespeare to write his own plays in Tamil.

\section{French Literature in Tamil Translation: Reception and Influence}

This period also marks the entry of serious literature into Tamil from European languages. For instance, the monumental works of Victor Hugo, Anatole France, Emile Zola, Guy de Maupassant, Alexandre Dumas, Balzac, Jules Verne and Moliere from French came to Tamil. Except some works, others were translated through English to Tamil and well received by Tamil readers. Among other literary genres, novel is the most translated form from early times to nowadays. Even now, novels dominate the ratio of translations published from French. There are many interesting factors involved in what made the novels to be translated the most.

Firstly, the novels of Victor Hugo were popular among Tamil readers because they were closely connected to the lives of the Tamils in nature. Les Miserables, one of the finest works of Hugo was translated twice and made into a film. Jeyamohan (2009: 41) says that Hugo's this particular novel was well received in Tamil literary circle because it has resemblances of the many aspects of Indian Kavya literature. Secondly, having seen the reception to translations, publishers showed much interest on other language literatures. This was the reason behind the publication of Alexandre Dumas's novels in Tamil which targeted children as their readers when the school syllabus had some portions of these translated novels. Thirdly, novels dealing with historical plots got prominence in Tamil as the famous writer Kalki Krishnamoorthy wrote novels extensively on Tamils historical heroes. This was subsequently resulted in the translations of Dumas novels in Tamil. Puthumaippithan accused Kalki of plagiarizing Dumas plots and producing novels with Tamil content. Therefore the advent of historical novel in Tamil has connections with French origins. Apart from these translations, Tamil had received the famous fictions of Maupassant, Emile Zola, Balzac and most importantly the likes of Jules Verne for his science fiction. His Around the world in 80 days has seen continuous translations from 1950s to recent times.

1980s mark a distinction in the history of translations from French into Tamil. It is because the trend of existentialist literature started coming into Tamil with Albert Camus's The Outsider which was translated directly from French in 1980. This novel so far has seen four editions in Tamil with corrections and additions 
made on every edition by the translator and editor. It also introduced a new way of writing fiction in terms of style, plot and theme. Other existentialist works like Antoine de Saint-Exupery's The Little Prince (1981) and Jean Paul Sartre's No Exit (1986) were also translated in the subsequent years which transformed the existing literary trend in Tamil. Literary creations with realistic notions were prominent in the late $70 \mathrm{~s}$ and these continuous translations gave new ideas of change in literary content and form. Eugène Ionesco, Marguerite Duras, Marguerite Yourcenar, Françoise Sagan, Jean Genet, Georges Perec are some of the other French authors who got their works translated into Tamil after the 1990s. These translations from French exposed new avenues of literary production to Tamil authors and readers. For instance, the novels by Sundara Ramasamy, Thamizhavan, Indira Parthasarathy, Charu Niveditha and many others influenced by the above said works in terms of narrative techniques, style and themes. Tamil writers took inspiration from these works and it is visible in their works. A detailed comparative study of these aspects would show that how French works received and influenced in Tamil literary scenario.

Along with literary translations, there were also other widely read translations of political ideas found some place in Tamil. Works of Voltaire and Rousseau got some important roles to play in the Tamil intellectual tradition. These translations were used as materials to propagate the ideas of political and social movements, particularly the Dravidian Movement which can be seen as case here.

\section{The case of Dravidian Movement}

Tamil Nadu had seen many social movements and individuals advocating for social justice. Annihilation of caste, eradication of untouchability and caste based hierarchy were the main objectives of these movements and individuals. At this time, Dravidian movement was to lead the struggles against the Brahmanical hegemony, birth based Varna system, annihilation of caste, widow re-marriage and so on. It emphasized these reforms and cultural changes to overcome the so-called feudal values that existed in the society. Dravidian movement used all possible mediums like journals, books and oratory speeches to disseminate its progressive thoughts. To do this effectively, it used many foreign literary and political texts in Tamil translation. French works were their major sources to spread their progressive ideology and thoughts. They were used to show the changing trends in the societal order of the western civilization and tried to show that adapting the changes in the west advocated by thoughts like, freedom, brotherhood and so on would help us to make our society in a better way.

French revolution which happened in the $18^{\text {th }}$ century is a great turning point in the world history. It was a revolution which predicted the pathway to fight against the atrocities of Kings and landlords. The political text written by Jean Jacques Rousseau, The Social Contract was the bible for who contributed to French revolution. After the revolution, critical literary and political texts were translated into many world languages. Translations of those texts were instrumental in shaping up the thought process of the suppressed people and to create a political consciousness among them. In Tamil context, by translating critical French texts into Tamil, leaders and intellectuals fuelled the struggle and believed that they would help to strengthen the movement. In the 1940s 50s and 60s many French texts were translated into Tamil from English and thus they tried to change the existing discriminations that prevails in Tamil society.

In 1945, C.N. Annadurai, one of the prime leaders of the Dravidian movement, in his speech at Annamalai University when he unveils the portrait of progressive poet of the same movement Bharathidasan who hails from Pondicherry, he says, "Pondicherry belongs to France; France is the birthplace of Freedom; When we were praising the Kings and rulers, they (French people) jailed them; When the words ruler and slave were being used here, words like Freedom and independence were the slogans of them..." (1971: 32-33). He goes further saying that "the breeze of France is being felt in Pondicherry... that is why Bharathidasan's poems are progressive; he is called as progressive poet" (1971: 35$)$.

C. N. Annadurai's articles in the journals emphasized 'France' as the focal point for freedom to Tamil people. Dravida Munnetra Kazhagam's (a prominent political organ in Tamil Nadu) main slogan 'Duty, Dignity, Decorum' was conceived by C.N. Annadurai with the French influence. Another leader of the movement C.P. Sitrarasu translated the biography of Emile Zola from English to Tamil. It was published in two parts in the year of 1952. The introduction says, "The reason behind the glory of France is only because of its 
progressive writers", it goes further in praising Emile Zola that he was the one who awakened his whole nation against evil forces. (1952: 3-4) The notable point here is, Emile Zola is basically a writer but he was introduced to the Tamil readers as a social activist. The change happened in the introduction of the book is to wake up the people towards the struggle for social justice. It was also a reaction by the Dravidian Movement to project a revolution based on collective ideas by people and not by weapons as the communists did. Thus Emile Zola's biography in Tamil was used in terms of advocating Dravidian ideology.

In 1956, C.N. Annadurai wrote a book about Emile Zola titled Ezhai Pangaalan (Partner of the Downtrodden). In this book he writes "Zola wrote for the people who were oppressed and suppressed by the existing social order, which means he used his writing in order to emancipate the common people. His writings are stronger than a warrior's sword." (1956: 82) By then, the head of DMK, C.N. Annadurai used Emile Zola's example to produce an alternative thinking as opposed to the current social order.

The thoughts of critical French thinkers in translation produced a great change in Tamil. For instance, in 1946 Puratchi Seitha Pena Veerar (Revolutionary Writers) a book written by P. Godandaraman deserves an important place in this line of argument. One of the chapters of the book entitled 'French Revolution' which explains and explores the progressive thoughts and activities of Voltaire, Rousseau, Diderot, Montesquieu and other important French thinkers. This book gives a detailed account of French revolution and how progressive thoughts of above said thinkers were instrumental in the success of French revolution. By this it is visible that leaders and intellectuals of Dravidian movement have always taken French ideas as their focal point for their ideological revolution.

The background and reason behind these translation oriented activities and other forms of knowledge dissemination is that writers, leaders and thinkers could write and translate without any barriers because nationalism was not a constrain at the time. There was no presence of state when the colonial rule was in place. One could talk and write of anything at the literary and political levels. But after the independence, the nationstate formation happens but the scenario does not change to a larger extent as people keep translating works from other European languages in general and from French in particular into Tamil. This is because the postindependence period translations are being done as to provide a status mark to writers and intellectuals. This is very much evident in the little magazine circles in Tamil. In sum, these translations are instrumental in the making of modern Tamil literary tradition.

\section{Puthumaippithan: Translator or Traitor?}

Puthumaippithan (1906-1948), a path breaking writer and translator in Tamil can be said to have initiated the making of modern Tamil literary cannon. He was an important fiction writer, especially short stories and translator thus got a pen name called 'Thennaattu Mauppasant' (Mauppasant of Southern India). He had translated almost 50 stories from other languages into Tamil, particularly the works of western and Russian writers such as Moliere, Mauppasant, Anatole France, Franz Kafka, Henrik Ibsen, Edgar Allan Poe, Jack London, Thomas Wolfe, Anton Chekhov, Maxim Gorky, Aleksandr Kuprin and others. Puthumaippithan was very much influenced by Maupassant as he was translating him regularly. Not only him, but others also translated Maupassant again and again even upto the late 1990s. His stories were well received as the publishers repeatedly publishing his works from time to time.

He had clear views on the differences between translations and adaptations. He strongly advocated having a continuous culture of translating other literatures into Tamil as it helps to know the current debates and advances in the contemporary literary world. But some of the critics in Tamil accused Puthumaippithan of having plagiarized the stories of French author Maupassant. It is notable that while publishing the stories, he had acknowledged the stories whenever he adapted a story. This was later made clear by his biographer that it was not Puthumaippithan but the editors committed the mistake after his death who compiled those volumes and published it as the stories written by him. Apart from these allegations, Puthumaippithan initiated the process of transformation of the new sensibility of the Tamil literary production with the translations from western languages in general and French in particular. 


\section{The Chinese Parallel Story}

The formation of Tamil literary tradition has a parallel story from Chinese history of literature. Wang Ning talks about the influence of translation of western literature on modern Chinese literature and elaborates how the modern Chinese literary tradition has been in the making from the early $20^{\text {th }}$ century to contemporary times. Ning cites the example of Lu Xun (1881-1936), one of the prolific writers and translators of modern Chinese literary history. Lu Xun continuously advocated the need of translation of western literature in Chinese and thus became the father of modern Chinese literature as considered by many. Ning further says that a famous slogan put forward by Lu Xun was the so-called 'grabbism', means grabbing anything useful to the Chinese through translation. By translating all the major cultural or literary currents, romanticism, realism and modernism, which dominated in Western literary circles over a hundred years were brought to China, exerting profound influence on the formation of modern Chinese literary tradition. Undoubtedly, translation of Western literature did promote the process of internalization of modern Chinese literature, making the literature of this period have a different look from its previous tradition (2011: 5). In other words, modern Chinese literature has formed its own unique tradition under the western influence through translation which is the base for modern Chinese literary tradition. Having the strong connection with western literature, Chinese literature is also able to come to terms with world literature.

\section{The Formation of Modern Tamil Literary Tradition}

Though Tamil has a profound cultural and literary history, its modern literature is very much a product of western literature in general and French literature in particular through translation. Writers like Puthumaippithan who had rich knowledge of both Tamil and western literature, advocated for the need of translation activities as a cultural and intellectual strategy. His literary works such as 'The Dream of Kuppan' express his sharp critique of narrow minded cultural character in the hero Kuppan. This is an important parallel to Lu Xun's short story, 'The True Story of Ah Q' which is as similar as the Puthumaippithan's above mentioned story. Therefore, one can say that as a result of such large-scale translation, effects of literary modernism are visible such as critiquing the narrow-mindedness of a culture in the works of these writers. Not only this, but also other aspects like poetics of various literary genres, narrative styles and other literary advancements happened in the milieu of translation. So as the theories of literature, literary criticism and academic research have been shaped by translation. Another aspect of literary modernity is the change found in the usage of literary and day-today language such as the recurrent use of passive structures, amalgamation of words of other languages and so on. This has to be studied in detail with regard to translation.

Translations play a crucial role in political affairs as it happened with the French works along with Dravidian movement. Here, one can observe that the boundaries of literature and politics have faded away and gave birth to a new category as 'political literature'. This is a fine example of what translations can potentially do in the target culture. Another notable point of reference is, in writing a modern Tamil literary history, translation should be regarded as to have played an important role. It is through translation that a new literature has been in the making which has helped to claim a place for Tamil literature in world literature. Therefore the role translation played in forming the modern Tamil literary cannon is more cultural, political than merely linguistic and formalistic. As compared with the enthusiastic translation and reception of western literature in Tamil, modern Tamil literature is little known to both scholars as well as ordinary readers in the western countries. Perhaps one of the important factors is the lack of translation.

\section{References}

[1] C. Kanaga Nayakam, "Shakespeare translations in a survey in Tamil," in Proc.1981 Fifth International Conference: Seminar of Tamil Studies., 1981, pp. 19-29.

[2] C.N. Annadurai, Eay thazhntha tamizhagame! (Oh! Debased Tamilnadu). $3^{\text {rd }}$ ed. Chennai, India: Muttamil Nilayam, 1971, pp. 32-35. 
[3] C.N.Annadurai, Ezhai pangalan (Partner of the Downtrodden). $1^{\text {st }}$ ed. Chennai, India: K.R. Narayanan Publishers, 1956, p.82

[4] C.P. Sittrarasu, Emile Zola (2 Parts), $1^{\text {st }}$ ed. Trichy, India: Tamil Mandram, 1952, pp. 3-4

[5] Jeyamohan, Novel kotpadu, $1^{\text {st }}$ ed. Chennai, India: Kizhakku Pathippagam, 2009, p.41

[6] Wang Ning, "Modernity, translated literature and the formation of modern Chinese literary tradition," in Proc.2011 Translating Modernity and (Re) Constructing World Literature Conf., 2011, p. 5 